\title{
'Thought Bank' for Peace through Dialogue and Co-Belonging
}

Thomas Menamparampil is the winner of Ambassador for Peace Award 2019 and retired Archbishop who took up office as the first Catholic archbishop of Guwahati in 1992. Prior to that, 84 year old prelate had been the bishop of Dibrugarh for 11 years. As a young priest he was in the field of education, working for many years in Don Bosco Technical School, and St. Anthony's College Shillong. Several of his students have emerged as prominent leaders in Northeast India and national levels. Of late he has been invited to several universities in India and abroad to speak on topics like inter-community understanding, healing of historic memories, and the arduous path to peace. He made a very useful contribution at the World Congress of Philosophers in 2018 in Beijing.

\section{Abstract}

Ring out the thousand wars of old, Ring in the thousand years of peace ${ }^{1}$

Are we heading for an era of Peace or a Third World War, for an age of Reason or of irrational Conflict? While we long for peace, what we hear every day is of clashes over religion, culture, language, natural resources, market, class, ideology, ethnicity, caste, gender and political interests. We also hear of neighbourhood tussles, domestic quarrels, social tensions, ethnic jealousy, urban violence, and communal anger... all these finding expression in aggressive vocabulary, prophetic denunciations, shrill voices, fearful threats, violent protests, prophetic denunciations and bomb blasts. All this would be true of South Asia as well. We notice deadly competitions over personal and group-interests, conflicts of ideas and ideologies, clash between action-groups, tensions over authority-subject relationships, and among movement's leaders. Political violence increases, accusations of corruption and counter-accusations of scams multiply, digital warfare and cyber aggression gather

${ }^{1}$ Alfred Tennyson, In memoriam, ed. Matthew Rowlinson (Canada: Broadview Editions). 
momentum. As Thomas Hobbes says. Having taken note of all this, let us ask ourselves: Can we not come together for the good of humanity? Can we not look forward to a time when prophetic persons will arise among us who will consider it their mission to bring peoples and communities together? ${ }^{2}$

\begin{tabular}{l}
\hline Key Words: Peace, Dialogue, Altruism, Thought-bank, \\
Co-belonging.
\end{tabular}

\section{Heroes/Heroines who will Bring Together the Human Family}

Bernard Shaw stated, "Peace is not only better than war, but infinitely more arduous."

However, such a task is not going to be easy. Everyone who fights feels he/she is fighting for a good cause, that he/she is giving expression to the legitimate anger of his/her people, and that his/ her point of view is perfectly correct; that it is the other side that is wrong, ought to listen, change, and accept his/her proposals for solution to problems. My question is, is it possible that I may be wrong in some areas of this contention, that the other party may be right at least in some respects? Will someone take the initiative of bringing us together? Can I attempt doing it?

Ancient heroes were conquerors, who subjugated nations, dominated societies and imposed their will on others. Recent heroes/ heroines have been those who struggled against domination, fought for freedom, for human dignity and the rights of the individual. A time is coming, and it is already here when ardent lovers of peace, men and women, will strive to the utmost of their ability to bring together the broken and scattered sections of humanity. Such persons will explain one to another, encourage, dialogue, reconcile, and restore unity to the human family. For we belong together. "All people are a single nation" says the Koran II. The future epics will be about such unbelievable tales of reconciliation.

\footnotetext{
${ }^{2}$ Centuries ago thus sang an Indian poet, "A bard am I, my father a leech, and my mother a grinder of corn. Diverse in means, but all wishing wealth, alike for cattle we strive" (Rig Veda x). Today may be our strife is for cash, not cattle; but the strife has persisted.
} 


\section{0/ Thomas Menamparampil}

Salesian Journal of Humanities and Social Sciences, Vol. X, No. 1. (May 2019) ISSN: 0976-1861 | DOI: 10.51818/SJHSS.10.2019.98-119 | Page: 98-119, Section: Article

\section{The Indian Tradition: A Concern for the Larger Cause of Humanity}

Tirukkural had observed, "To be one with the world is wisdom."

There is no higher duty than the welfare of the whole world. (Asoka's Rock Edict VI)

For us Indians it is not a difficult concept to understand. Ours is a civilization that respected diversity and allowed the simultaneous flourishing of different races, schools of thought, religious convictions, traditions, and viewpoints, and worked towards common goals. The collective unconscious of our great society seems to tell us that there is something valid in every point of view, and that everyone's interest deserves attention. If we could return to this central inspiration of our civilization, we could bring to life the spirit behind these words of Asoka "There is no higher duty than the welfare of the whole world." (Rock Edict VI).

Nehru echoed the sentiment in his 'tryst with destiny speech' when he said, "It is fitting that at this solemn moment we take the pledge of dedication to the service of India and her people and to the still larger cause of humanity." Tagore felt that whatever has been said wisely anywhere in the world belonged to him as well. All of us belong to all. Could we develop further this 'universal outlook' on wider human concerns that these great representatives of our civilization had?

\section{We Need Silk Roads that Link, not China Walls that Exclude}

No man is an island, entire itself; every man is a piece of the continent, a part of the main. ${ }^{3}$

Such noble sentiments were expressed not only in our country, but in every part of the world by people who desired to translate these ideals into life. People longed to communicate with each other, near and far. Communications created a sense of common belonging and roused a sense of responsibility for each other. Asoka sent out missionaries in all directions carrying a message of peace and social concern. Similar messages travelled from India to southeast

${ }^{3}$ John Donne, No man is an Island (Souvenir Press Ltd. 1988). 
Asia and the shores of China, even as the bearers of the Christian Gospel and the teachings of Islam reached India's western coast. As the Silk Road linked China with the West and carried technical knowledge and ideas both ways, the Karakorum Highway took Buddhist insights to central Asia. ${ }^{4}$ People like Fahien and Hiuen Tsang made their way to Nalanda and other places sacred to the memory of the Great Buddha. The Dakshin Path carried ideas northand-south within India itself. ${ }^{5}$

For, no one is an island; everyone belongs to a great whole. Everyone wants to communicate and share. Diogenes said, "I am not an Athenian or a Greek, but a citizen of the world".

Today we need to initiate communication, not only between nations and regions, but also between ideas, ideologies, convictions, and persuasions. Let ideas talk to each other. For as John Maynard Keynes says, "Ideas shape the course of history". However, many like to build a great China Wall around themselves and the concepts they have of what is best for the world. Neither those impressive walls in China nor Hadrian's wall in England ultimately succeeded to keep intruders out. After all, ideas have legs, walls have ears, and thoughts keep travelling and reaching ultimately places from where they were most excluded. The solution then is dialogue, interaction and mutual sharing; not ethnic isolation, inward looking nationalism, ideological close-mindedness, communal passion, mutual incrimination, or inter-movement strife.

Our negative ideas accumulate. How easily we stereotype each other along cultural, ethnic, national or religious lines, descending to slurs and jokes that can have a cumulative effect. "Each individual message gains its power because of the cumulative and reinforcing effect of countless similar messages..."6

Centuries ago, Akbar introduced dialogue between the Hindus, Muslims, Christians, Jains, Parsis, Jews, agnostics and ${ }^{4}$ John Keay, A History of India (London: Harper Collins, 2000), 115.

${ }^{5}$ Keay, A History of India, 119.

${ }^{6}$ Charles Lawrence, as quoted in Christine Gudorf \& Lauritzen, Paul, ed., Studies in Christian Ethics, Vol. 1 (Kottyam: Andreas-Punnoose Publishing Co., 2010), 79. 


\section{2/ Thomas Menamparampil}

Salesian Journal of Humanities and Social Sciences, Vol. X, No. 1. (May 2019) ISSN: 0976-1861 | DOI: 10.51818/SJHSS.10.2019.98-119 | Page: 98-119, Section: Article

atheists. ${ }^{7}$ This was an interesting experiment those days, though it met with limited success. But the very gesture promoted healthy relationships between communities and fruitful collaboration. Today we may have to include among our dialogue partners not only people with religious differences, but also ideological, ethnic, regional, linguistic, and cultural differences. There is nothing like free interaction of ideas to open out new vistas. Arthur Thomson said, "The most powerful factors in the world are clear ideas in the minds of energetic men of good will". Our call today is to become such men and women who will remember that "Every human being has a responsibility for injustice anywhere in the community", commented Scott Buchanan.

\section{Those who Facilitate Communications Help}

The most immutable barrier in nature is between one man's thoughts and another's. ${ }^{8}$

When William Jones or Max Muller translated the Sacred Books of the East for a Western readership they brought the two worlds closer. While Mahmud of Ghazni brought ruin to several parts of India during his aggressive campaigns, his travelling companion, Alberuni, opened out possibility for the Indian and Arab worlds to enter into dialogue. He mastered Sanskrit, translated Indian texts on mathematics, natural sciences, literature, philosophy and religion into Arabic language. The Ramayana was translated into Bengali by Muslim Pathans. It is acted in drama form in Buddhist Thailand and Muslim Indonesia. Arab scholars in Spain introduced Indian Mathematics and Greek philosophy into western universities. Indian Buddhist writings were translated into Chinese; Chinese philosophy was put into western languages which greatly influenced Enlightenment thinkers; western political thought and sciencerelated literature have been translated almost into all languages of the world. With faster translations and easier communications, human society is coming into continuous interaction and dialogue

${ }^{7}$ Amrtya Sen, The Idea of Justice, (London: Allen Lane, Penguin, 2009), 37.

${ }^{8}$ Helen Demetriou, Empathy, Emotion and Education (UK London: Palgrave Macmillan Publishers Ltd., 2018), 52. 
'Thought Bank' for Peace through Dialogue and Co-Belonging /103 Salesian Journal of Humanities and Social Sciences, Vol. X, No. 1. (May 2019)

ISSN: 0976-1861 | DOI: 10.51818/SJHSS.10.2019.98-119 | Page: 98-119, Section: Article

with each other, so much so that people are beginning to talk of cothinking and a global brain.

In today's world you will notice that there are more persons and groups that are skilled in widening the gaps between people than bridging distances. We need others who can lead conflicting communities even a wee bit closer! That is why Asoka suggested restraint in speech. ${ }^{9}$ When he said that by disparaging someone else's sect one inflicted damage on oneself, he was inviting reflection on the plain truth that over-concern for one's sectarian interests is merely counter-productive. Not being magnanimous to others is itself self-injury. ${ }^{10}$ This may be a message greatly needed in the South Asian context today.

We spoke of the need for language-translators. In the present situation we feel the need of culture-translators, persons who can explain ways, styles and ideas of one ethnic group, culture or civilization to others. When Alexander showed interest in Jain monks, he opened doors for successive generations of Greek thinkers to take interest in other ways of thinking than their own. Persons who you think are different from you are not altogether different. We need people today who can make us understand this truth and interpret one community to another; one school of thought to another; followers of one ideology to those of another; one set of movement leaders to another. For, the whole human story is not told until all have spoken.

\section{When Emotions Run High, it is Hard to Open Dialogue}

A riot is the language of the unheard. (Martin Luther King, speech at St Louis, 22.3.64)

When emotions run high over an issue, dialogue becomes difficult. Undoubtedly we cannot ignore the role of emotions in human affairs. We have to concede something to feelings strongly expressed by persons who have suffered a great deal. People who have lost

\footnotetext{
${ }^{9}$ Amartya Sen, The Argumentative Indian, (London: Allen Lane, Penguin, 2005), 182.

${ }^{10}$ Sen, The Idea of Justice, 75.
} 


\section{4/ Thomas Menamparampil}

Salesian Journal of Humanities and Social Sciences, Vol. X, No. 1. (May 2019) ISSN: 0976-1861 | DOI: 10.51818/SJHSS.10.2019.98-119 | Page: 98-119, Section: Article

relatives and property in an ethnic clash, for example, may not be masters of themselves when they are discussing events and issues. Communities that have been oppressed for generations and those who could not give utterance to their feelings for a very long time, may adopt dramatic ways of expressing their sorrow or grievance. What drives them at a given moment may be more their resentment than reasoning power.

Persons who are used to handling rational argument in a serene atmosphere may find themselves helpless in such a situation. But, given space and time for self-expression, even the most unreasonable and discordant voices can turn milder, the language used acceptable, and logic consistent. There are persons, who are specially gifted or who have equipped themselves with the needed skills for ferrying people across their emotions to normal processes of reasoning.

Amartya Sen admitted that instinctive reactions are understandable in human situations, but insisted that unscrutinized instincts cannot be allowed to have the final say on matters. ${ }^{11}$ "Outrage can be used to motivate, rather than replace, reasoning", he says. ${ }^{12}$ Crude and rough protests must be confronted with 'openminded engagement in public reasoning ${ }^{\prime}{ }^{13}$ Angry rhetoric must be followed by reasoned arguments. ${ }^{14}$

The more stubborn I remain in my argument, with greater determination will my opponent strive to blunt the pointedness of my argument and use a moment of my weakness to push off my thrust at a tangent. These elementary truths are clean forgotten even by champions of great causes, heads of states, and representatives of aggressive religious movements, whether it be in North Korea, Syria, Iran, Afghanistan, Ayodhya; over the use of the Tsampo (Brahmaputra) waters, or Cavery River. Such tactics only further delay the solution to problems. Violent attempts to hasten the

${ }^{11}$ Ibid., 51.

12 Ibid., 389.

${ }^{13}$ Ibid., 390.

${ }^{14}$ Ibid., 391. 
process can even put it off indefinitely. Gradually mutual criticism puts on teeth, cynicism grows, hostility mounts, violence erupts in unexpected ways.

If, on the contrary, at some stage of the struggle I change my attitude and I decide to turn my grievance into a stimulating message, the entire atmosphere changes. I meet with receptivity and attention, and readiness to listen and change.

In Justice Questions, Study Issues from Diverse Angles. Only justice will actually, finally, end terrorism. Violence only creates more violence. ${ }^{15}$

We know from experience that justice is an emotional issue, and when the starting point is a clear case of perceived injustice, it is extremely difficult to put a distance between strong emotions and a reasonable debate. It is true that emotion can serve a great purpose. It can bring people together and commit them to a cause even at great sacrifice. It can help to motivate people to gather related information fast, go into action without loss of time. But if emotion does not have reason for an ally, it goes off the rails and sends you marching double-quick in the opposite direction. That is what usually happens soon after an emotionally charged group takes over a situation. And this happens all too often.

Amartya Sen takes enormous pain in his book 'The Idea of Justice' to make it evident that the concept of justice can be understood quiet differently in different social situations, historic contexts and by diverse communities. He does not see any possible consensus on the concept of a 'perfectly just social arrangement', any more than on deciding whether Mona Lisa is the best picture in the world. ${ }^{16}$ He asks whether it would not be more realistic to strive to reduce injustice and advance the cause of justice in different cases than to set entire peoples after utopian goals of justice, treading on human beings all along the way and leading them ultimately to frustration.

${ }^{15}$ Susan Brooks, "New Wars Old Wineskins", in Strike Terror No More: A Theology, Ethics and the New War ed. Jon L. Berquist (St. Louis MO: Chalice Press, 2002), 264.

${ }^{16}$ Ibid., 15-16. 


\section{6/ Thomas Menamparampil}

Salesian Journal of Humanities and Social Sciences, Vol. X, No. 1. (May 2019) ISSN: 0976-1861 | DOI: 10.51818/SJHSS.10.2019.98-119 | Page: 98-119, Section: Article

The 'just' War at Kurukshetra lasted only 18 days, but it wiped out entire races.

Similarly, why do we tend to make of our democracy something like a 'competition of Furies'? Why do we adopt an ideology of exclusion of other traditions and other points of view? Why do our political activists seek to intimidate people or influence public opinion through political violence, throwing stones, burning buses and planting explosives in cinema halls and market places, damaging historical monuments, demonizing opponents, having recourse to the character assassination of the rival, communal riots, gheraos, and rasta rokos? We need not be over-confident about the persuasive power of such uncreative juggleries. These are not ways in which an intelligent argument can be carried forward. Concern for others and their ways of thinking, made evident, has greater power of persuasion.

\section{Altruism is Rational and Human}

All the great systems of ethics preach absolute unselfishness as the goal. Every selfish action retards our reaching the goal, and every unselfish action takes us towards the goal. ${ }^{17}$

We are familiar with Bentham's utilitarian theory which proposes the greatest happiness of the greatest number. However, we know that economic advantage alone is not the only source of happiness. Outsmarting others and accumulating wealth do not necessarily lead to utmost happiness. Let us take an example: what if someone's happiness comes from serving the least privileged in society? ${ }^{18}$

It is evident that a dedicated altruist is not less rational, less intelligent or less human than a shrewd profit-maker. We human beings are naturally inclined to feel a sense of fiduciary responsibility towards the weaker ones. ${ }^{19}$ Even a person like Francis Edgeworth

\footnotetext{
${ }^{17}$ Marakand R. Paranjape, ed. Swami Vivekananda: A Comtemporary Reader (London: Routeledge, 2015), 24.

${ }^{18}$ Ibid., 59.

${ }^{19}$ Ibid., 251.
} 
admitted that the human being is most part an 'impure egoist' and a 'mixed utilitarian' ${ }^{20}$; which means, he is generous too.

In fact, an egoist who is far-sighted knows that single-minded pursuit of self-interest will only alienate others and damage his own long-term interests. There is very little evidence to show that our advantage is best served by being 'nasty, brutish and short' as Hobbes described human beings. ${ }^{21}$ Why does Hobbes forget that humans can also feel sympathy and be touched by the pain of others; and that even after people argue, disagree and even fight, they can concur, and become caring towards each other ? ${ }^{22}$

\section{Fighters Produce Fighters}

"In the future no one wins a war" claimed Brock Chisholm.

In an inter-personal or inter-community difference, never humiliate your opponent. Never hurt a community's collective selfhood. Do not allow any dispute to turn into an ongoing prestige-struggle. Even the weakest have some measure of self-respect. They will fight back to affirm it. Unfortunately you put your best talent into challenging others, and you have earned what you never desired. "The world will never have lasting peace so long as men reserve for war the finest human qualities." 23 As long you keep your best energies for struggle, peace never comes. You can easily see that the radicalization of one community (Hindu or Muslim, India or Pakistan) leads to the radicalization of the other.

History tells us that fighters produce fighters, till all turn fighters. After all, most societies passed through the stages not only of being hunters and gatherers, but also of being invaders, marauders, intruders, and crusaders. That instinct is with us. We do not need too much of provocation to get it ablaze. Christopher Dawson

${ }^{20}$ Ibid., 184.

${ }^{21}$ Ibid., 415.

${ }^{22}$ Ibid., 414-415.

${ }^{23}$ Roy B. Zuck, ed. Devotions for Kindered Spirits (Eugene, Oregon: Wipf \& Stock Publishers, 2007), 33. 


\section{8/ Thomas Menamparampil}

Salesian Journal of Humanities and Social Sciences, Vol. X, No. 1. (May 2019) ISSN: 0976-1861 | DOI: 10.51818/SJHSS.10.2019.98-119 | Page: 98-119, Section: Article

reminds us that in Homer's world all were fighters: only knights, retainers, princes, and pirates; no citizens, priests or merchants. The same was true of the Germanic people in the $5^{\text {th }}$ and $6^{\text {th }}$ centuries. ${ }^{24}$

The possibility of such a scenario re-emerging on the world stage is not hard to visualize. When I move into the field absolutely conscious of my rights, but not educated enough about others' rights, about the limits of my own rights, a dignified way of affirming my rights, and persuasive way of regaining lost rights, I may be hurting my long term interests. It is not an intelligent approach to my problems. We must help people to emerge from their martyrcomplexes, not add to their accumulated anger. We must suggest creative ways to the solution of problems and to single-minded commitment to the cause of peace.

\section{The Irrationality of Deterrence, the Beauty of Compromise}

The day when nobody comes back from a war it will be because the war has been properly organized. Would it be a good message for Kim and Trump today?

Wars have always been cruel whether fought by the Mongols or the Nazis, Attilas or Hitlers or Stalins; whether in Korea, Vietnam, in the 'killing fields' of Cambodia, on the heights of Kargil, or in communal clashes in different parts of India; whether presently conflict arises from ethnic pride, exaggerated nationalism, religious fanaticism, political ambition or economic greed; whether the struggle is between mighty nations, tiny political units, or armed young men on street corners.

Today nations are arming themselves to the point of collective suicide in deterrence, acquiring weapons beyond their economic strength. Did it happen to Saddam Hussein? Is it what is happening to Kim? To India on the China and Pakistan borders? After India's first successful experiment with a nuclear device, Bhutto shrieked

${ }^{24}$ Christopher Dawson, Dynamics of World History (Wilmington, Delaware: ISI Books, 2002), 158. 
'Thought Bank' for Peace through Dialogue and Co-Belonging / 109 Salesian Journal of Humanities and Social Sciences, Vol. X, No. 1. (May 2019) ISSN: 0976-1861 | DOI: 10.51818/SJHSS.10.2019.98-119 | Page: 98-119, Section: Article

that Pakistan would go hungry, would eat grass, but would develop a nuclear device in response. Which he did: six blasts for five.

As of now, India is turning out to be the biggest purchaser of arms in our times in the world. Norman Cousins says, the possibility of war increases in direct proportion to the effectiveness of the instruments. The more prepared I am, the more provocative I appear. Either side can take the initiative. And once the war breaks out, no one has full control; instead of the government taking over the industry to make it serve its purposes, the industry takes over the government to make it serve its greed, says Claire Gillis.

With the recent awakening of the Asian Powers, we pray, the European tragedies of the $20^{\text {th }}$ century may not be repeated in Asia....in our immediate regard, in South Asia.

An entire new world can open out before us if we seek to understand the meaning of Mahatma Gandhi's phrase, the 'beauty of compromise', and work for cooperation.

\section{Uniting People with Ideologies of Hatred or an 'Anti-Other' Attitude}

As said by Konrad Lorez:

The instinctive need to be the member of a closely knit group for common ideals may grow so strong in a group of people that it becomes inessential what these ideals are.

Thus people are misled into deceptive ideologies.

Historically speaking, charismatic personalities were able to bring people together by the strength of their personality or the strength of their arms. But ultimately it has always been proved that people could be held together for a considerable length of time only by committing them to some great ideals and goals.

Here too lies a danger. As in earlier times people were easily forced or seduced into subjection by rulers who played on their greed for booty or ambition for conquests, there have emerged in 


\section{0/ Thomas Menamparampil}

Salesian Journal of Humanities and Social Sciences, Vol. X, No. 1. (May 2019) ISSN: 0976-1861 | DOI: 10.51818/SJHSS.10.2019.98-119 | Page: 98-119, Section: Article

recent times leaders who have the skill of reducing people to the status of blind followers, playing on their anger and resentment against real or perceived exploitation. Millions have died in bloody revolutions and many more continue to be held slaves to ideologies of hatred. They need to be rescued.

Christopher Dawson shares with us a perceptive insight when he says it is precisely the intellectuals without social responsibilities that become a seedbed for theories of violence. He sees leaders of revolutionary and terrorist movements rising, not from the peasant or the proletariat classes, but from the middle ranks and from the irresponsible bourgeois class. ${ }^{25}$ Vitriolic social criticism too often springs from among people with no sense of responsibility or solidarity, mere self-interest being their main concern. ${ }^{26}$

Such theoreticians emerge as a new type of religious prophets. Nazis referred to the people who slaughtered in their behalf as 'priests'. All recent ideologies like fascism, Nazism, communism manifested symptoms of pseudo-religious pathologies and were busy with quasi-religious activities such as brainwashing new recruits, extorting confession, hunting heresies, and re-educating those that erred in ideology. They eagerly looked forward to the emergence of a new man, a new heaven, and a new earth. Not surprisingly, such teachers came from families that had some religious connection. ${ }^{27}$

'Fanatic nationalism', including the Indian version, makes global peace uncertain. Sub-nationalism threatens healthy nationalism; ethnic loyalty weakens even sub-national movements. On the other hand hegemonic tendencies of majoritarian groups threaten nation-states, government-sponsored terrorism limits the freedom of democratic movements, and the so-called people's movements working at cross-purposes reduce the usefulness of all of them.

\footnotetext{
${ }^{25}$ Dawson, Dynamics of World History, 238.

${ }^{26}$ Ibid., 240.

${ }^{27}$ Michael Burleigh, Sacred Causes, (London: Harper Press, 2006), xii.
} 
Observers are beginning to predict that America's interference in Iraq and Afghanistan is bound to be its end, as it proved to be for the Soviet Union. ${ }^{28}$ But the interesting thing to note is that every aggressive nation, movement, ideological thrust meets with 'its own Afghanistan' in due time. It is only the wise and the prudent that find a way of avoiding this sort of a 'terminal ailment'.

Can we act as these 'wise and prudent' individuals that help to bring down anger in human hearts? Can we be like the 'lamb of God' who takes away the 'anger of the world'? Is there no way of keeping at a distance tragedies like those of the Twin Towers, Bamiyan Buddhas, Holocaust, Hiroshima, Ayodhya, Bhopal, Chernobyl, Gulag, Jihad, culture wars, Killing Fields, Taj Hotel, clash with dalits?

\section{Building Unity on the Enthusiasm for a Growing Economy}

According to Confucius, the superior man understands what is right; the inferior man understands what will sell.

Amazing things are happening today. We are witnessing a global growth, and the emerging economy is accounting for half this growth. ${ }^{29}$ More and more people in the developing world are being absorbed into a productive and growing economy. They cease to be objects, and become players on their own right. And as the world comes closer and inter-connected, it sets in motion a virtuous cycle of growth, but unfortunately also a vicious cycle of depression.

As manufacturer and saver, China comes first. ${ }^{30}$ She has become the workshop of the world, as Britain was in the nineteenth century. She has begun to contribute more to global growth than America by the sheer volume of her consumer demands. The Chinese have preserved their pragmatism and competence. ${ }^{31}$ They realize that

${ }^{28}$ Fareed Zakaria, The Post-American World (New Delhi: Penguin Books India, 2008), 173.

${ }^{29}$ Zakaria, The Post-American World, 20.

${ }^{30}$ Ibid., 92.

${ }^{31}$ Ibid., 105. 


\section{2/ Thomas Menamparampil}

Salesian Journal of Humanities and Social Sciences, Vol. X, No. 1. (May 2019) ISSN: 0976-1861 | DOI: 10.51818/SJHSS.10.2019.98-119 | Page: 98-119, Section: Article

China can exercise power only through the market, not building empires. ${ }^{32}$ Let us turn now our attention to India. Her growth rate during the last few years has been impressive. As China pumps out goods, India excels in services. As of now, India has more billionaires than any other Asian country, most of them self-made. The private initiative of the average Indian is amazing. "The government sleeps at night and the economy grows", claims Gurucharan Das.

There is a limit to all these Asian possibilities. Inter-national tensions keep the Asian nations continuously in defensive positions against each other. Deterrence adds to the anxiety. Arms-selling Mighty Powers aggravate the problem further. Social tensions in each country in every direction leave many things unpredictable. After each explosion, whether it was at Madrid, London, or Bali, the economy dipped, at least for some time. That is why building national unity only on the strength of the enthusiasm created by a growing economy is fragile. No doubt, it has some value at the present moment, and we need to take maximum advantage of it. Success itself is a motivation for further success and united efforts towards it.

\section{Civilization as a Uniting and Motivating Force more Precious than Economic Assets}

"Neither man nor nation can exist without a sublime idea", said Feodor Dostoevski.

We need to look at the social tensions we have been describing above and all the economic and political uncertainties we experience, in the context of a wider reality called 'Civilization'. This reality has something to do with the glory of our collective past, the joys and pains of the present, and the shape of things to come as we pursue our ultimate destiny. While the political society is an association for practical ends, civilization is a spiritual communion..$^{33}$ It cannot be bought or sold, budgeted or planned. It is the spiritual heritage of a people which has taken shape over generations, over centuries.

${ }^{32}$ Ibid., 108.

${ }^{33}$ Dawson, Dynamics of World History, 54-55. 
Everyone benefits from it, and can make a small contribution towards its development. But a civilization's processes cannot be rushed through direct intervention. Plato tried to reform Sicily by giving the young tyrant lessons in mathematics. ${ }^{34}$ In this endeavour he failed. But the ideas he left behind gave a new direction to the entire history of the western world.

Great societies like those of the Indians or the Chinese have a rich cultural heritage within the context of which they work out solutions to their problems and make a contribution to human growth. In these days there is a renewed understanding of the traditions linked with Asian civilizations, e.g. with Buddhism, Confucianism, Hinduism or Islam. They are showing their strength and are looked up to with respect. They have been great and have played a great role in different periods of history. We remember, for example, that the forerunners of Enlightenment were inspired by the Confucian classics. ${ }^{35}$

Nations whose innovative ideas turn out to be relevant and inspiring, gradually begin to make an impact on others. There was a time when Indian insights were considered inspiring and when she acted as a 'soft power', as Jose Nye calls it, exerting influence by the very attractiveness of the ideas that she generated. In reality, this sort of soft power is a 'mighty power'. For, they change the world.

Arms assail and crush, economy entices and enslaves, ideas enlighten and befriend. D.T.Suzuki, referring to a British team that claimed to have conquered Everest, said, "We Orientals would have spoken of befriending Everest," not conquering the great heights. ${ }^{36}$ Unfortunately there are also weaknesses that cling to civilizations which act as a deadweight on them. Such negative cultural assets are a drag on communities and keep them behind in the global race for better times and better things. In the Indian context, we may speak of fear of manual labour, the drawback of caste and gender

${ }^{34}$ Ibid., 188.

${ }^{35}$ Zakaria, The Post-American World, 109-110.

${ }^{36}$ Huston Smith, The World's Religions (New Delhi: Harper Collins Publishers India, 1997), 212. 


\section{4/ Thomas Menamparampil}

Salesian Journal of Humanities and Social Sciences, Vol. X, No. 1. (May 2019) ISSN: 0976-1861 | DOI: 10.51818/SJHSS.10.2019.98-119 | Page: 98-119, Section: Article

prejudices, and the lack of thoroughness in things. These have serious economic and social consequences. And if problems like an inclination to corruption, political militancy, lack of cooperative spirit, and indifference to untidiness, are neglected, they can become an unrenounceable part of our cultural heritage dragging us to dust.

\section{Civilizations and Cultures in Rapid Transition}

For Gandhiji, patriotism was same as humanity. "I am patriotic when I am human and humane", he said.

Today civilizations and cultures are in crisis. They are in rapid transition. When the ideals and values on which they were built get marginalized, the society concerned goes through an experience of self-alienation and an estrangement from its collective self. The insecurity it generates leads it to a frantic search for a substitute. If the society chooses to re-affirm the ideals and values on which it was established, it witnesses a revival of its ancient glory. Not willing to pay the price of returning to the deeper values linked with its original genius, the society opts for an alternative: glorification of an artificially constructed 'self', a distorted form of the original, an unreal collective being. In the Roman Empire it took the form of emperor-worship, ending up in statolatria. Effectively, it is selfworship forgetting the real identity of the self; in fact, worship of the 'false self'.

This happened in Japan and in many nation-states of Europe before World War II. For example, a distorted form of German identity-Aryan-Nordic-pure race-was placed before people inviting public obeisance and fanatic loyalty. This Nazi irrationality has been sufficiently exposed since; but other nation-states too were not far behind in sacrificing human lives to the cause of imperialism and exaggerated forms of nationalism. Most pre-War political history was political propaganda for nation states. ${ }^{37}$

There is a school of thought in India today that refuses to learn from such negative experiences and is eager to drag the nation

${ }^{37}$ Dawson, Dynamics of World History, 4. 
into the same sort of idolatry, worship of a distorted form of our 'collective self'. It is our hope that the nation escapes the excesses that humanity has witnessed in the past when a fringe group of Fascists takes over the destinies of their people into their hands.

\section{Gathering People Together around Great Values and High Ideals}

"Leaders have a significant role in creating the state of mind that is in society", once said John Gardner.

H.G. Wells used to say that thinkers were far more significant as shapers of history than politicians. ${ }^{38}$ This paper is an invitation to thought; in fact, to the building up of a "Thought-Bank" that will lead to dialogue and to a sense of co-belonging. The unity imposed by dominant personalities or by exploiting minorities in the form of a dominating State has limited future. We have seen that selfworship is suicidal. Similarly, the togetherness built on people's anger, ambition or ignorance by enticing them with ideologies of hatred, is counterproductive. In the same way, the enthusiasm constructed on impressive successes in economy, like successes in empire-building, can last only for a brief while.

Only the unity based on the spiritual bonds provided by our common ideals will have the strength to hold together our diverse cultural and religious groups, economic and political interests, ideological and philosophical perceptions. When we shall learn to give greater importance to our civilizational heritage of dharmasatya-ahimsa (uprightness-truth-nonviolence) and other values promoting solidarity, mutual concern and a sense of common belonging, expressed in today's vocabulary and in lived out in dynamic ways and relevant forms, shall we begin to regain our lost vital energies. If they are brought to actual life situations, they will manifest their strength and validity once again.

With growing violence and corruption in our country, there is no denying the fact that our ideals and values are under threat today. And this threat comes from those trends in our society that 


\section{6/ Thomas Menamparampil}

Salesian Journal of Humanities and Social Sciences, Vol. X, No. 1. (May 2019) ISSN: 0976-1861 | DOI: 10.51818/SJHSS.10.2019.98-119 | Page: 98-119, Section: Article

weaken our moral fibre, social bonds, sense of common belonging, and commitment to shared values and ideals, easy inclination to corruption, unabashed egotism and party spirit, majoritarianism, an attitude of exclusion, and closed-minded sectarian thinking.

According to Dawson, as individuals and communities grow "deracinated and despiritualized", they become self-centred and forget the sources of their moral vitality: family, region, local clay and their spiritual roots. They fail to draw energy and motivation from the organic and life-giving dimension of culture and lose the ability to see the sublime in the ordinary and greatness in themselves. It is in such situations of helplessness that people, especially the youth, develop attitudes that are aggressive and contentious, grow stubborn and unbending.

\section{A Unifying Spiritual Vision}

Those trees that stand erect, growing close together, are competent to resist winds more violent still, owing to mutual dependence (Mahabharata, Udyog Parva Sec. 36)

Behind every civilization there is a unifying vision of reality ${ }^{39}$ In our case, it is a 'spiritual vision', and it is the most important element in a culture. For, it is at that level we stand face to face with the Ultimate Reality as a community. And as we have a glimpse of that Reality, we begin to perceive the divine in the daily events of our lives, and within the prosaic nature and the materiality of every day. This is the ability that will bring a blessing upon us every day of our life. As we move away from being an agricultural society, whose main concern was the mystery of life as noticeable in the soil and vegetation, ${ }^{40}$ and as we begin to deal with more lifeless things within closed doors like dead furniture, lifeless equipment, laptops, profits and bank balances, we should never lose our love for life, respect for living things, and our loyalty to life-giving principles, Ideals and Values. And these are far more enthralling and enriching than the mysteries of the market. They lead us to new forms of discoveries

${ }^{39}$ Ibid., 42.

${ }^{40}$ Ibid., xxi-xxii. 
to thrill the hearts that are searching for ultimate meanings. People are tired of the ephemeral excitement that the present shopping culture provides. They are looking for something deeper.

That is why we firmly believe that there is hope even in desperate conditions, in the most helpless situations. Adam Smith admitted that "even the greatest ruffian, the most hardened violator of the laws of society", is not without some concern for others, ${ }^{41}$ he added that qualities like sympathy, generosity and public spirit are ingrained in human beings. ${ }^{42}$ Serious students of human nature are convinced that the cleaver promotion of self-interest is not the only "Rational Choice Theory" that people make. They know that they have received much from others and ought to give back something in return. They are eager to give attention to healthy relationships that build up the human family.

They feel a sense of obligation to other living creatures as well. Their concern extends to the whole of nature, to animals and vegetation. Buddha thought that human beings being stronger, have some special responsibility towards other weaker species, as a mother has for her child. ${ }^{43}$

Let us then be Agents of Togetherness and light up the lives of people with inspiring ideas, ideals and values that speak about the human family as one and the human cause as identical. Ardent lovers of their own country like Gandhi, Nehru, Tagore, Sun Yat-sen, or others were never exclusive. Persons specially committed to their own communities like the Dalai Lama, Mandela, or Martin Luther King, still had a universal outlook. They were the representatives of the entire human family. With the right approach, we are bound to succeed. "There is one thing stronger than all the armies in the world: and that is an idea whose time has come", remarked Victor Hugo. May be such a time has come for human togetherness. However, it can only come from the inner conscious of being united in one heart. Mahatma Gandhi said, "Such power as I possess for

\footnotetext{
${ }^{41}$ Sen, The Idea of Justice,19.

${ }^{42}$ Ibid., 185.

${ }^{43}$ Ibid., 204-205.
} 


\section{8 / Thomas Menamparampil}

Salesian Journal of Humanities and Social Sciences, Vol. X, No. 1. (May 2019) ISSN: 0976-1861 | DOI: 10.51818/SJHSS.10.2019.98-119 | Page: 98-119, Section: Article

working in the political field has derived from my experiments in the spiritual field."

\section{Every Community must Contribute from its own Resources}

"Let the lives and hearts of the sons and daughters of my country be one, my God", noted Tagore.

Everyone makes a start from his own situation using the means he/she has and inspired by the lights he/she holds. Every ethnic group looks to its own prophets for guidance. Every religious group does the same. But we share with each other what we have. Martin Luther King, speaking of human destiny uses similar cosmic language, "We are caught in an inescapable network of mutuality; tied in a single garment of destiny...I can never be what I ought to be until you are what you ought to be. You can never be what you ought to be until I am what I ought to be. This is the way the world is made. I did not make it this way, but this is the interrelated structure of reality." ${ }^{44}$ King built his faith in God, "the creative force in the universe that works to bring the disconnected aspects of reality into a harmonious whole." ${ }^{45}$

Whenever we say a kind word or perform a kind deed, whenever we whisper an assurance of forgiveness, whenever we bring together people alienated from one another, whenever we offer encouragement to the weak and a correction to the strong, whenever we call people to reflection and self-correction, whenever we try to ease tension and explain one group to another, whenever we promote the virtues of compassion, kindness, generosity, fairness, and concern for others in ourselves and in others we make a small contribution to bringing people together. You hear a whisper:

Be united;

Speak in harmony;

Let your minds apprehend alike;

Common be your prayer;

${ }^{44}$ Christine Gudorf \& Lauritzen, Paul, ed., Studies in Christian Ethics, (Kottayam: Andreas-Punnoose Publishing Co, 2010), 127.

${ }^{45}$ Christine Gudorf \& Lauritzen, Paul, ed., Studies in Christian Ethics, 129. 
'Thought Bank' for Peace through Dialogue and Co-Belonging / 119

Salesian Journal of Humanities and Social Sciences, Vol. X, No. 1. (May 2019)

ISSN: 0976-1861 | DOI: 10.51818/SJHSS.10.2019.98-119 | Page: 98-119, Section: Article

Common be the end of your assembly;

Common be your resolutions;

Common be your deliberations;

Unified be your hearts;

Common be your intentions;

Perfect be your unity (Rig Veda 10,191,24). 